J. Dairy Sci. 95:6557-6562

http://dx.doi.org/10.3168/jds.2011-4808

(C) American Dairy Science Association ${ }^{\circledR}, 2012$.

\title{
Effects of dietary betaine on milk yield and milk composition of mid-lactation Holstein dairy cows
}

\author{
S. E. Peterson, ${ }^{\star}$ P. Rezamand, ${ }^{\star 1}$ J. E. Williams, ${ }^{\star}$ W. Price,$\dagger$ M. Chahine,${ }^{\star} \ddagger$ and M. A. McGuire ${ }^{\star}$ \\ *Department of Animal \& Veterinary Science, \\ †College of Agricultural and Life Sciences, and \\ fUniversity of Idaho Twin Falls Research \& Education Center, University of Idaho, Moscow 83844
}

\section{ABSTRACT}

Betaine, naturally found in plants and an oxidative product of choline, is converted to acetate in the rumen, which may be used for milk fat synthesis. The objective of this study was to determine the effect of supplemental dietary betaine on milk yield and milk composition. Eighteen Holstein dairy cows (126 \pm 5 $\mathrm{d}$ in milk; mean $\pm \mathrm{SD}$ ) were randomly assigned to a sequence of treatments of rumen-unprotected betaine at $0,25,50$, and $100 \mathrm{~g} / \mathrm{d}$ added to a standard lactation ration in a $4 \times 4$ Latin square design. Animals were fed individually with feed intake and milk yield recorded daily. Body condition score and body weight were recorded on the last day of each period that lasted $16 \mathrm{~d}$, with milk sampled on the last $2 \mathrm{~d}$ of each period. Milk composition was determined by a Dairy Herd Improvement Association laboratory and milk fatty acids were determined by gas chromatography. Data collected over the last 2 to $3 \mathrm{~d}$ were analyzed using the MIXED procedure in SAS (SAS Institute Inc., Cary, NC). Milk yield (mean \pm SEM) was increased by betaine when fed at $100 \mathrm{~g} / \mathrm{d}(22.4,22.5,22.8,24.1 \pm 1.19 \mathrm{~kg} / \mathrm{d}$ for 0 , 25,50 , and $100 \mathrm{~g}$ of betaine/d, respectively). No effect of dietary betaine was detected on dry matter intake, feed efficiency, body weight, or body condition score. Percentages of milk fat, lactose, solids-not-fat, and somatic cell count were not altered; however, protein concentration was decreased by betaine supplementation as compared with the control $(3.35,3.28,3.27$, and $3.28 \pm 0.07 \%$ for $0,25,50$, and $100 \mathrm{~g}$ of betaine/d, respectively). Daily yields of milk protein, fat, lactose, energy-corrected milk, and $3.5 \%$ fat-corrected milk did not differ with betaine supplementation. Overall, inclusion of dietary betaine at $100 \mathrm{~g} / \mathrm{d}$ increased milk yield, whereas all levels of betaine supplementation decreased milk protein percent and slightly altered milk fatty acid profile. Further studies are needed to determine the

Received August 8, 2011.

Accepted August 2, 2012.

${ }^{1}$ Corresponding author: rezamand@uidaho.edu ruminal fermentation characteristics and the optimum rate of supplemental betaine for dairy cows.

Key words: betaine, milk yield, milk fatty acid

\section{INTRODUCTION}

Betaine, naturally present in wheat and sugar beets, is an oxidative product of choline and a trimethylated derivative of glycine (de Zwart et al., 2003). Commercially available betaine is a coproduct of the sugar beet industry (Lever and Slow, 2010) and is extracted from molasses by water-based chromatographic separation and crystallization (Craig, 2004). Betaine functions as an osmolyte to maintain cell function and volume, a methyl donor to increase methionine and decrease homocysteine concentrations, and is fermented to acetate in the rumen (Mitchell et al., 1979).

Supplemental rumen-unprotected betaine fed at $4 \mathrm{~g} /$ $\mathrm{kg}$ of the diet has been demonstrated to increase milk yield, milk fat content, and the concentration of the FA synthesized de novo in lactating dairy goats (Fernández et al., 2004a,b, 2009a). Fernández et al. (2009b), however, detected no changes in milk yield of lactating dairy goats fed betaine at $4 \mathrm{~g} / \mathrm{kg}$ of the diet, although an increase in the concentration of medium-chain FA was observed. Recently, Wang et al. (2010) reported increased yields of milk, milk fat, ECM, $4.0 \%$ FCM, and milk fat percentage in lactating dairy cows fed rumenunprotected betaine at $100 \mathrm{~g} / \mathrm{d}$. However, Davidson et al. (2008) reported no alteration in milk yield and components when feeding $100 \mathrm{~g} / \mathrm{d}$ rumen-protected betaine to lactating dairy cows. Thus, the response of milk production and composition to dietary betaine is equivocal in goats and limited in cows. Therefore, the objective of this study was to determine the effect of supplemental dietary betaine on milk yield and milk composition in mid-lactation dairy cows.

\section{MATERIALS AND METHODS}

\section{Animals and Treatments}

Eighteen Holstein dairy cows (126 \pm 5 DIM; mean \pm $\mathrm{SD})$ weighing $623( \pm 16$; mean $\pm \mathrm{SD}) \mathrm{kg}$ were blocked 
by parity and randomly assigned to a sequence of treatments in a $4 \times 4$ Latin square design with 4 periods and 4 treatments of rumen-unprotected betaine (betaine 97\% purity; Amalgamated Sugar Co., Nampa, ID) at $0,25,50$, and $100 \mathrm{~g} / \mathrm{d}$ top-dressed on a lactation ration (Table 1) formulated to meet the nutrient requirements of a cow producing $22 \mathrm{~kg}$ of milk/d (NRC, 2001). Betaine was mixed with dried distillers grain to equal a total amount of $200 \mathrm{~g}$. Each period lasted $16 \mathrm{~d}$ with a washout day in between each period and milk sampled on the last $2 \mathrm{~d}$ of each period. Milk composition (fat, protein, and lactose, determined by infrared spectroscopy with a Bentley 2000 mid-infrared milk analyzer; Bentley Instruments Inc., Chaska, MN) and SCC (determined by flow cytometry with a Somacount 300 instrument; Bentley Instruments Inc.) were analyzed by a certified DHIA laboratory (Burlington, WA). Energy-corrected milk yield was calculated as (milk yield, $\mathrm{kg} / \mathrm{d} \times 0.327$ ) $+($ milk fat, $\mathrm{kg} / \mathrm{d} \times 12.86)+($ milk protein, $\mathrm{kg} / \mathrm{d} \times$ 7.65 ) and $3.5 \%$ FCM was calculated as (milk yield, $\mathrm{kg} / \mathrm{d}$ $\times 0.4324)+($ milk fat, $\mathrm{kg} / \mathrm{d} \times 16.2162)$ according to Davidson et al. (2008). Cows were housed in a freestall

Table 1. Feed ingredients and analyzed nutrient composition $^{1}$ of the basal ration and analyzed nutrient composition of betaine ${ }^{2}$

\begin{tabular}{lcc}
\hline Item & Amount & SEM \\
\hline Ingredient, \% of DM & & \\
Alfalfa hay & 13.7 & \\
Triticale silage & 23.0 & \\
Rolled barley & 16.5 & \\
Ground corn & 15.4 & \\
Canola meal & 16.5 & \\
Distillers grain & 12.2 & \\
Vitamin-mineral premix ${ }^{3}$ & 2.4 & \\
Sodium bicarbonate & 0.5 & \\
Nutrient composition & & \\
DM, \% & 50.9 & 0.76 \\
CP, \% of DM & 18.0 & 0.15 \\
Soluble protein, \% of CP & 30.0 & 1.53 \\
ADF, \% of DM & 22.3 & 1.92 \\
NDF, \% of DM & 35.5 & 2.04 \\
NFC, \% of DM & 34.4 & 1.89 \\
Crude fat, \% of DM & 4.3 & 0.21 \\
Ash, \% of DM & 7.9 & 0.16 \\
TDN, \% of DM & 68.7 & 1.33 \\
Calcium, \% of DM & 0.77 & 0.04 \\
Phosphorus, \% of DM & 0.56 & 0.05 \\
Magnesium, \% of DM & 0.33 & 0.03 \\
Potassium, \% of DM & 1.67 & 0.14 \\
NE, Mcal/kg & 1.61 & 0.03 \\
\hline
\end{tabular}

${ }^{1}$ Nutrient analysis [near-infrared (NIR) and wet chemistry analysis; Dairy One Cooperative Inc., Ithaca, NY] as performed on 3 composited samples (3-wk composites) from all periods.

${ }^{2}$ Betaine (95.1\% of DM) used contained (on DM basis) CP $(75 \%)$, soluble protein (100\% of CP), ADF (0.3\%), NDF (0.4\%), NFC (24.4\%), starch $(1.1 \%)$, crude fat $(0.2 \%)$, TDN $(91 \%)$, Ca $(0.003 \%), \mathrm{K}(0.03 \%)$, and $\mathrm{NE}_{\mathrm{L}}(2.2 \mathrm{Mcal} / \mathrm{kg})$.

${ }^{3}$ Vitamin-mineral premix contained Ca $(17.5 \%)$, P $(0.17 \%)$, S $(0.3 \%)$, $\mathrm{Mg}(3.1 \%), \mathrm{Fe}(0.08 \%), \mathrm{Zn}(0.28 \%) \mathrm{Mn}(0.17 \%)$, Se (0.001\%), vitamin $\mathrm{A}(275 \mathrm{kIU} / \mathrm{kg})$, vitamin D $(77 \mathrm{kIU} / \mathrm{kg})$, and vitamin $\mathrm{E}(1,320 \mathrm{IU} / \mathrm{kg})$. barn and fed individually using Calan gates (American Calan Inc., Northwood, NH) with water available at all times. Feed intake and orts were measured daily. Cows were milked twice daily at 0500 and $1700 \mathrm{~h}$, and BW and BCS were measured on d 16 of each period. Cows were weighed after milking and before feeding, and body condition scored while in lockups using a score of 1 to 5 , where a score of 1 indicates emaciation and a score of 5 indicates obesity (Wildman et al., 1982). Two trained individuals scored cows every period and scores were averaged. All animal procedures were approved by the University of Idaho (Moscow) Animal Care and Use Committee (protocol 2009-38).

\section{Sampling}

Milk samples were obtained twice daily on d 15 and 16 of each period. Milk samples were kept refrigerated and transported to the laboratory after the morning and evening milking. Milk samples from each day were pooled proportionately by yield. Total mixed ration samples were obtained daily and stored at $-20^{\circ} \mathrm{C}$. Daily TMR samples were composited into weekly samples and then composited into 3-wk samples. The nutrient composition of TMR and betaine samples were determined by Dairy One Cooperative Inc. (Ithaca, NY) via near-infrared (NIR) analysis, whereas the mineral composition of these samples was determined via wet chemistry (Table 1).

\section{Milk, Betaine, and TMR FA Analysis}

Milk and betaine lipids were extracted using 2:1 chloroform:methanol (Clark et al., 1982) and methylated using base-catalyzed transesterification (Christie, 1982). Ground freeze-dried TMR and betaine samples were methylated in a 2-step procedure using methanolic $\mathrm{HCl}$ and sodium methoxide according to Kramer et al. (1997).

The FA composition was determined using a gas chromatograph (Agilent 7890a series with autoinjector; Agilent Technologies Inc., Santa Clara, CA) fitted with a flame ionization detector and a $100-\mathrm{m} \times 0.25$ $\mathrm{mm}$ (with $0.2-\mu \mathrm{m}$ film) capillary column coated with (88\%-cyanopropyl)-methylarylpolysiloxane (Agilent Technologies Inc.). The carrier gas was hydrogen at a column flow rate of $2 \mathrm{~mL} / \mathrm{min}$ and hydrogen flow to the detector was $40 \mathrm{~mL} / \mathrm{min}$ with a detector temperature of $280^{\circ} \mathrm{C}$. After sample injection, the oven temperature was $120^{\circ} \mathrm{C}$ for $1 \mathrm{~min}$ and then increased to $175^{\circ} \mathrm{C}$ at a rate of $10^{\circ} \mathrm{C} / \mathrm{min}$ and held for $10 \mathrm{~min}$, and then increased to $210^{\circ} \mathrm{C}$ and held for $5 \mathrm{~min}$, and then increased to $230^{\circ} \mathrm{C}$ at a rate of $5^{\circ} \mathrm{C} / \mathrm{min}$ and held for $5 \mathrm{~min}$. To identify $\mathrm{FA}$, retention times were compared with a 
butter oil standard with certified values (CRM 164; European Community Bureau of Reference, Brussels, Belgium) and a Supelco 37 FA methyl ester (FAME) standard mixture (Sigma-Aldrich, St. Louis, MO).

\section{Statistical Analysis}

Data were analyzed in a $4 \times 4$ Latin square design assuming 4 treatments $0,25,50$, and $100 \mathrm{~g}$ of betaine and 4 periods. In each period, a total of 18 cows were used, leading to 2 squares with 4 cows and 2 squares with 5 cows. All statistical computations were conducted in MIXED procedures of SAS (version 9.2; SAS Institute Inc., Cary, NC). Treatment means were compared using pairwise comparisons with a Tukey adjustment to control the experimentwise error rate. Significance was declared at $P<0.05$.

\section{RESULTS AND DISCUSSION}

The experiment was completed with no incidences of clinical disease.

\section{Betaine FA Composition}

The NIR analysis yielded $0.16 \%$ crude fat in betaine. However, betaine samples yielded close to $0 \%$ lipid when extracted with 2:1 chloroform:methanol and when analyzed by GC, no FA were detected.

\section{Milk Yield}

An increase in milk yield (22.4 to $24.1 \mathrm{~kg} / \mathrm{d})$ was observed for cows consuming $100 \mathrm{~g}$ of dietary betaine/d (Table 2) as compared with 0,25 , and $50 \mathrm{~g}$ of betaine/d (overall betaine effect: $P=0.02$ ). This is in agreement with several studies that demonstrated an increase in milk yield in lactating dairy goats $(1.47$ to $2.0 \mathrm{~kg} / \mathrm{d}$ : Fernández et al., 2004b; 1.32 to $1.48 \mathrm{~kg} / \mathrm{d}$ : Fernández et al., 2004a) fed $10 \mathrm{~g}$ of rumen-unprotected betaine/d and an increase in milk yield in lactating dairy cows (26.0 to $26.7 \mathrm{~kg} / \mathrm{d}$; Wang et al., 2010) with supplementation of $100 \mathrm{~g}$ of rumen-unprotected betaine/d. In other studies, however, milk yield was not increased by rumen-unprotected betaine supplementation in lactating dairy goats (Fernández et al., 2009a,b) or cows fed rumen-protected betaine (Davidson et al., 2008). When betaine is supplemented, rumen fermentation decreases betaine concentrations, with an increase in acetate concentrations (Mitchell et al., 1979). An increase in acetate was shown to increase the rate at which milk is synthesized in some studies (Rook and Balch, 1961; Rook et al., 1965; Purdie et al., 2008) but not in all (Rook, 1979; Lough et al., 1983). The results reported here indicate that milk yield was increased with supplementation of $100 \mathrm{~g}$ of betaine/d without detectable changes in protein or lactose secretion, possibly due to the magnitude of the increase.

\section{Milk Composition}

Milk Protein Percentage and Milk Protein Yield. Milk protein percentage was decreased (overall betaine effect: $P=0.005$ ) by betaine supplementation (Table 2). In previous experiments however, dietary betaine had no detectable effect on milk protein percentage of lactating dairy cows (Davidson et al., 2008; Wang et al., 2010) or goats (Fernández et al., 2004b).

Milk protein yield was not affected $(P=0.34)$ by betaine supplementation. Previous findings indicate that milk protein yield was not affected by feeding of rumen-protected betaine (Davidson et al., 2008) or rumen-unprotected betaine (Wang et al., 2010) supplementation. Overall, milk protein yield was not affected

Table 2. Dry matter intake and milk component yields and percentages from mid-lactating Holstein cows fed varying levels of dietary betaine

\begin{tabular}{|c|c|c|c|c|c|c|}
\hline \multirow[b]{2}{*}{ Item } & \multicolumn{4}{|c|}{ Betaine, $\mathrm{g} / \mathrm{d}$} & \multirow[b]{2}{*}{ SEM } & \multirow{2}{*}{$\begin{array}{c}\text { Treatmen } \\
P \text {-value }\end{array}$} \\
\hline & 0 & 25 & 50 & 100 & & \\
\hline DMI, $\mathrm{kg} / \mathrm{d}$ & 19.0 & 19.0 & 18.2 & 20.2 & 1.08 & 0.18 \\
\hline \multicolumn{7}{|l|}{ Milk production, $\mathrm{kg} / \mathrm{d}$} \\
\hline Milk yield & $22.4^{\mathrm{a}}$ & $22.5^{\mathrm{a}}$ & $22.8^{\mathrm{a}}$ & $24.1^{\mathrm{b}}$ & 1.19 & 0.02 \\
\hline Milk fat & 0.86 & 0.82 & 0.78 & 0.85 & 0.06 & 0.37 \\
\hline Milk protein & 0.75 & 0.75 & 0.75 & 0.79 & 0.04 & 0.34 \\
\hline Milk lactose & 1.04 & 1.05 & 1.07 & 1.12 & 0.07 & 0.13 \\
\hline \multicolumn{7}{|l|}{ Milk composition, $\%$} \\
\hline Milk protein & $3.35^{\mathrm{a}}$ & $3.28^{\mathrm{b}}$ & $3.27^{\mathrm{b}}$ & $3.28^{\mathrm{b}}$ & 0.07 & 0.005 \\
\hline Milk fat & 3.77 & 3.61 & 3.43 & 3.56 & 0.15 & 0.30 \\
\hline Milk lactose & 4.54 & 4.58 & 4.58 & 4.61 & 0.10 & 0.42 \\
\hline $\mathrm{SCC}(\times 1,000 / \mathrm{mL})$ & 398 & 318 & 388 & 296 & 181 & 0.36 \\
\hline
\end{tabular}

$\overline{\mathrm{a}, \mathrm{b}}$ Means within a row that do not share a common letter are significantly different $(P<0.05)$. 
by betaine supplementation, although milk protein percent decreased.

Milk Fat Percentage and Milk Fat Yield. Milk fat percentage did not differ $(P=0.30)$ among treatments by betaine supplementation. Studies demonstrated that milk fat content remained unchanged with rumen-protected (Davidson et al., 2008) or rumenunprotected betaine (Fernández et al., 2004a, 2009b) supplementation in lactating dairy cows and goats, respectively. In contrast, milk fat content increased as a result of betaine supplementation in lactating dairy goats (Fernández et al., 2004b, 2009a) and early- to mid-lactation dairy cows (Wang et al., 2010). Within the rumen, betaine is converted to acetate by microorganisms (Mitchell et al., 1979) and acetate is directly correlated with milk fat (Bauman and Griinari, 2003).

No difference was detected in milk fat yield $(P=$ $0.37)$ with betaine supplementation. Similarly, no difference was detected in the yields (means \pm SEM) of $3.5 \%$ FCM $(24.0,23.2,22.5$, and $24.0 \pm 1.48 \mathrm{~kg} / \mathrm{d}$ for $0,25,50$, and $100 \mathrm{~g}$ of betaine/d, respectively; $P=$ $0.34)$ with betaine supplementation as well as the yields (means \pm SEM) of ECM $(24.2,23.5,22.5$, and $24.4 \pm$ $1.43 \mathrm{~kg} / \mathrm{d}$ for $0,25,50$, and $100 \mathrm{~g}$ of betaine $/ \mathrm{d}$, respectively; $P=0.35$ ).

Milk $\boldsymbol{S C C}$. Somatic cells play a protective role against infectious disease in the bovine mammary gland. No differences were observed for milk SCC $(P=$ $0.36)$ relative to betaine supplementation. These results are similar to those reported previously (Fernández et al., 2004a,b, 2009a). No clinical infections were detected during the experimental period.

\section{Milk FA}

$\boldsymbol{S F A}$. No differences were observed for SFA content of milk individually or in total $(P=0.89$ for the sum of C4:0 to C20:0) as well as the sum of the FA synthesized de novo, including $\mathrm{C} 4: 0$ to $\mathrm{C} 16: 0(P=0.86)$ with betaine supplementation (Table 3). Fernández et al. (2004a) reported similar results in lactating dairy goats, demonstrating that the sum of C4:0 to C20:0 was not different as a result of betaine supplementation, although individual FA, including C8:0, C10:0, and C12:0, increased with betaine supplementation. Furthermore, Fernández et al. (2004b) reported an increase in C8:0, C10:0, C12:0, and C17:0 as well as an increase in the sum of $\mathrm{C} 6: 0$ to $\mathrm{C} 20: 0$ as a result of betaine supplementation in lactating dairy goats. In another study, the sum of the SFA was not altered with betaine supplementation; however, C12:0, C14:0, and C15:0 increased with betaine supplementation, whereas C16:0 decreased in lactating dairy goats (Fernández et al., 2009b). Furthermore, the effects of dietary betaine on the sum of the FA synthesized de novo have not been previously reported.

MUFA. No effect of betaine supplementation was detected on the sum of MUFA trans C10:1, C14:1, C15:1, C16:1, C17:1, C18:1 isomers, and cis-9 C18:1 $(P=0.93)$ with betaine supplementation (Table 3$)$, although a difference was detected in the individual FA C15:1 $(P=0.04)$. Similarly, Fernández et al. (2009b) reported that betaine did not affect the sum of MUFA including C10:1 to C17:1, although C15:1 was not included in the sum as in the present study. In another study, Fernández et al. (2004b) demonstrated increases in milk $\mathrm{C} 10: 1$ and $\mathrm{C} 18: 1$ as well as the sum of C10:1, C16:1, and C18:1. Fernández et al. (2004a) did not detect a difference in C18:1 as a result of betaine supplementation. Further, Jensen (2002) reported a concentration of milk $\mathrm{C} 15: 1$ at $0.3 \%$, similar to the current experiment.

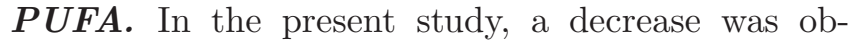
served in the sum of PUFA, including cis-9, cis-12 C18:2, cis-6, cis-9,cis-12 C18:3, cis-9, cis-12,cis-15 C18:3, cis-9,trans-11 C18:2, cis-11,cis-14 C20:2, and cis-11,cis-14,cis-17 C20:3 $(P=0.02)$, with all levels of betaine supplementation (Table 3 ), although the individual PUFA were not altered in response to betaine supplementation. Fernández et al. (2009b) reported that betaine supplementation did not change the sum or individual PUFA, including trans $\mathrm{C} 18: 2$, cis-9, cis-12 C18:2, cis-9,cis-12,cis-15 C18:3, cis-9,cis-11 C18:2, and cis-5,cis-8,cis-11,cis-14 C20:4, in milk. Furthermore, the sum of the PUFA, including C18:2 (linoleic) and C18:3 (linolenic), did not change with betaine supplementation (Fernández et al., 2004a,b), although individually, C18:3 (linolenic) increased in lactating dairy goats (Fernández et al., 2004b).

\section{DMI}

Dry matter intake did not differ $(P=0.19)$ among treatments by betaine supplementation. In agreement, previous studies reported that DMI was unaffected by rumen-protected betaine (Davidson et al., 2008) and rumen-unprotected betaine (Wang et al., 2010) supplementations in lactating dairy cows. However, Löest et al. (2002) observed an increase in DMI in steers when rumen-unprotected betaine was top-dressed on the upper one-fourth of the ration, which might have increased palatability of the ration and stimulated intake.

\section{Feed Efficiency}

Feed efficiency, including milk production divided by $\operatorname{DMI}(1.29,1.28,1.33$, and $1.26 \pm 0.07 \mathrm{~kg} / \mathrm{d}$ for $0,25,50$, and $100 \mathrm{~g}$ of betaine/d respectively; means 
Table 3. Milk FA (weight percentage of total identified FA) from mid-lactating Holstein cows fed varying rates of dietary betaine

\begin{tabular}{|c|c|c|c|c|c|c|}
\hline \multirow[b]{2}{*}{ FA } & \multicolumn{4}{|c|}{ Betaine, $\mathrm{g} / \mathrm{d}$} & \multirow[b]{2}{*}{ SEM } & \multirow{2}{*}{$\begin{array}{c}\text { Treatment } \\
P \text {-value }\end{array}$} \\
\hline & 0 & 25 & 50 & 100 & & \\
\hline C4:0 & 2.00 & 2.04 & 1.98 & 2.05 & 0.09 & 0.94 \\
\hline C6:0 & 1.77 & 1.71 & 1.69 & 1.70 & 0.03 & 0.17 \\
\hline $\mathrm{C} 8: 0$ & 1.14 & 1.14 & 1.08 & 1.10 & 0.03 & 0.40 \\
\hline C10:0 & 2.63 & 2.47 & 2.46 & 2.52 & 0.08 & 0.26 \\
\hline C12:0 & 3.17 & 2.99 & 2.97 & 2.97 & 0.11 & 0.30 \\
\hline C13:0 & 0.13 & 0.13 & 0.12 & 0.13 & 0.01 & 0.39 \\
\hline C14:0 & 10.61 & 10.27 & 10.21 & 10.39 & 0.20 & 0.40 \\
\hline C15:0 & 1.17 & 1.15 & 1.15 & 1.19 & 0.03 & 0.72 \\
\hline C16:0 & 29.64 & 30.72 & 31.20 & 30.41 & 0.86 & 0.43 \\
\hline C17:0 & 0.56 & 0.57 & 0.54 & 0.56 & 0.02 & 0.79 \\
\hline C18:0 & 10.59 & 10.38 & 10.43 & 10.51 & 0.51 & 0.94 \\
\hline $\mathrm{C} 20: 0$ & 0.18 & 0.15 & 0.16 & 0.15 & 0.01 & 0.22 \\
\hline C10:1 & 0.36 & 0.35 & 0.34 & 0.34 & 0.02 & 0.40 \\
\hline C14:1 & 1.43 & 1.47 & 1.41 & 1.46 & 0.10 & 0.68 \\
\hline C15:1 & $0.33^{\mathrm{a}}$ & $0.32^{\mathrm{a}}$ & $0.30^{\mathrm{b}}$ & $0.32^{\mathrm{a}}$ & 0.01 & 0.04 \\
\hline C16:1 & 1.71 & 1.75 & 1.85 & 1.77 & 0.13 & 0.72 \\
\hline C17:1 & 0.26 & 0.26 & 0.26 & 0.27 & 0.01 & 0.96 \\
\hline trans $\mathrm{C} 18: 1$ isomers $^{1}$ & 2.79 & 2.87 & 2.78 & 2.72 & 0.11 & 0.42 \\
\hline cis-9 C18:1 & 24.63 & 24.70 & 24.46 & 24.85 & 0.56 & 0.92 \\
\hline cis-9,cis-12 C18:2 & 2.87 & 2.68 & 2.67 & 2.65 & 0.10 & 0.11 \\
\hline cis-6,cis-9,cis-12 C18:3 & 0.11 & 0.10 & 0.11 & 0.11 & 0.004 & 0.16 \\
\hline cis-9, cis-12, cis-15 C18:3 & 0.40 & 0.36 & 0.40 & 0.38 & 0.02 & 0.10 \\
\hline cis- 9, trans-11 C18:2 & 0.87 & 0.87 & 0.85 & 0.84 & 0.04 & 0.81 \\
\hline cis-11,cis-14 C20:2 & 0.33 & 0.24 & 0.23 & 0.28 & 0.04 & 0.25 \\
\hline cis-11,cis-14,cis-17 C20:3 & 0.31 & 0.26 & 0.27 & 0.29 & 0.02 & 0.17 \\
\hline Unsaturated:saturated ratio ${ }^{2}$ & 0.58 & 0.57 & 0.57 & 0.57 & 0.02 & 0.90 \\
\hline$\Sigma$ PUFA $^{3}$ & $4.90^{\mathrm{a}}$ & $4.51^{\mathrm{b}}$ & $4.53^{\mathrm{b}}$ & $4.60^{\mathrm{b}}$ & 0.14 & 0.02 \\
\hline$\Sigma \mathrm{SFA}^{4}$ & 63.50 & 63.69 & 63.98 & 63.66 & 0.68 & 0.89 \\
\hline$\Sigma$ Unsaturated $^{5}$ & 36.40 & 36.23 & 35.92 & 36.27 & 0.68 & 0.89 \\
\hline$\Sigma$ MUFA $^{6}$ & 31.51 & 31.71 & 31.39 & 31.72 & 0.61 & 0.93 \\
\hline$\Sigma$ de novo $^{7}$ & 50.87 & 51.32 & 51.59 & 51.14 & 0.83 & 0.86 \\
\hline \multicolumn{7}{|c|}{$\overline{\mathrm{a}, \mathrm{b}}$ Means within a row that do not share a common letter are significantly different $(P<0.05)$. } \\
\hline \multicolumn{7}{|c|}{${ }^{1}$ trans $\mathrm{C} 18: 1$ isomers $=$ the sum of trans $\mathrm{C} 18: 1$ isomers including trans- 6 to trans- 11.} \\
\hline${ }^{2}$ Unsaturated:saturated ratio & um of the & isaturate & A divide & y the su & of the $\mathrm{S}$ & \\
\hline${ }^{3} \Sigma$ PUFA $=$ the sum of $c i s-9$ & $18: 2-c$ & 1, cis-14, & $17 \mathrm{C} 20:$ & (a) & & \\
\hline \multicolumn{7}{|c|}{${ }^{4} \Sigma \mathrm{SFA}=$ sum of $\mathrm{C} 4: 0$ to $\mathrm{C} 20: 0$} \\
\hline \multicolumn{7}{|c|}{${ }^{5} \Sigma$ Unsaturated $=$ the sum of MUFA and PUFA. } \\
\hline \multicolumn{7}{|c|}{${ }^{6} \Sigma \mathrm{MUFA}=$ the sum of cis-9 $\mathrm{C} 10: 1$ to $\mathrm{C} 18: 1$} \\
\hline${ }^{7} \Sigma$ de novo $=$ the sum of $\mathrm{C} 4: 0$ & $\mathrm{C} 10: 0, \mathrm{C}$ & & & & & \\
\hline
\end{tabular}

$\pm \mathrm{SEM} ; P=0.80)$, FCM divided DMI $(1.45,1.38$ 1.40 , and $1.27 \pm 0.09 \mathrm{~kg} / \mathrm{d}$ for $0,25,50$, and $100 \mathrm{~g}$ of betaine/d, respectively; means \pm SEM; $P=0.47)$, and ECM divided by DMI $(1.46,1.40,1.43$, and $1.29 \pm 0.09$ $\mathrm{kg} / \mathrm{d}$ for $0,25,50$, and $100 \mathrm{~g}$ of betaine/d, respectively; means \pm SEM; $P=0.52$ ), were not affected by betaine supplementation. These results are similar to those of previous studies where feed efficiency was unaffected by rumen-protected betaine (Davidson et al., 2008) and rumen-unprotected betaine supplementation (Wang et al., 2010).

\section{$B C S$ and $B W$}

Body condition score (mean $\pm \mathrm{SEM}$ ) was not affected $(2.58,2.64,2.59$, and $2.63 \pm 0.05$ for $0,25,50$, and
$100 \mathrm{~g}$ of betaine/d, respectively; $P=0.28$ ) by betaine supplementation. Body weight (mean $\pm \mathrm{SEM}$ ) was not affected $(601,605,596$, and $608 \pm 16.1 \mathrm{~kg} / \mathrm{d}$ for 0,25 , 50 , and $100 \mathrm{~g}$ of betaine/d, respectively; $P=0.08$ ) by betaine supplementation either. Effects of feeding rumen-unprotected betaine have not been previously reported regarding BCS and BW.

\section{CONCLUSIONS}

Dietary betaine supplementation increased milk yield, milk fat percentage, and the FA synthesized de novo in some studies. Overall, the present study confirms that $100 \mathrm{~g}$ of dietary rumen-unprotected betaine/d increased milk yield and all levels of betaine supplementation slightly altered the milk FA profile and decreased milk 
protein percentage. No change, however, was detected in yields of milk components. Furthermore, dietary betaine did not alter milk fat or lactose percentage, ECM, $3.5 \%$ FCM, BW, or BCS in the present study. Further studies are needed to determine the ruminal fermentation characteristics and optimum rate of supplemental betaine for dairy cows and its effect on rumen fermentation.

\section{ACKNOWLEDGMENTS}

Funding for this project was, in part, awarded by The Amalgamated Sugar Company, (Nampa, ID) to M. Chahine. Funding was also provided by the Idaho Agricultural Experimental Station (Moscow). The authors acknowledge J. Peak, S. L. Shields, D. L. Sevier, and J. K. Kinch (all of the University of Idaho, Moscow) for technical assistance with this project.

\section{REFERENCES}

Bauman, D. E., and J. M. Griinari. 2003. Nutritional regulation of milk fat synthesis. Annu. Rev. Nutr. 23:203-227.

Christie, W. W. 1982. A simple procedure for rapid transmethylation of glycerolipids and cholesteryl esters. J. Lipid Res. 23:1072-1075.

Clark, R. M., A. M. Ferris, M. Fey, P. B. Brown, K. E. Hundrieser, and R. G. Jensen. 1982. Changes in the lipids of human milk from 2 to 16 weeks postpartum. J. Pediatr. Gastroenterol. Nutr. 1:311-315.

Craig, S. A. S. 2004. Betaine in human nutrition. Am. J. Clin. Nutr. $80: 539-549$.

Davidson, S., B. A. Hopkins, J. Odle, C. Brownie, V. Fellner, and L. W. Whitlow. 2008. Supplementing limited methionine diets with rumen-protected methionine, betaine, and choline in early lactation Holstein cows. J. Dairy Sci. 91:1552-1559.

de Zwart, F. J., S. Slow, R. J. Payne, M. Lever, P. M. George, J. A. Gerrard, and S. T. Chambers. 2003. Glycine betaine and glycine betaine analogues in common foods. Food Chem. 83:197-204

Fernández, C., J. Fontecha, M. A. Latorre, C. Garcés, M. Soler, and J. M. de la Fuente. 2004a. Influence of betaine on goat milk production and composition. S. Afr. J. Anim. Sci. 34(Suppl. 1):165-168.

Fernández, C. C. Mata, O. Piquer, F. Bacha, and J. M. de la Fuente. 2009a. Influence of betaine on goat milk yield and blood metabolites. Trop. Subtrop. Agroecosyst. 11:209-213.

Fernández, C., L. M. Rodríguez-Alcalá, E. Abilleira, J. M. de la Fuente, and J. Fontecha. 2009b. Influence of betaine on milk yield and fatty acid composition in lactating dairy goats. J. Appl. Anim. Res. 36:89-92.

Fernández, C., P. Sanchez-Seiquer, A. Sánchez, A. Contreras, and J. M. de la Fuente. 2004b. Influence of betaine on milk yield and composition in primiparous lactating dairy goats. Small Rumin. Res. 52:37-43.

Jensen, R. G. 2002. Invited review: The composition of bovine milk lipids: January 1995 to December 2000. J. Dairy Sci. 85:295-350.

Kramer, J. K., V. Fellner, M. E. R. Dugan, F. D. Sauer, M. M. Mossoba, and M. P. Yurawecz. 1997. Evaluating acid and base catalysts in the methylation of milk and rumen fatty acids with special emphasis on conjugated dienes and total trans fatty acids. Lipids $32: 1219-1228$.

Lever, M., and S. Slow. 2010. The clinical significance of betaine, an osmolyte with a key role in methyl group metabolism. Clin. Biochem. 43:732-744.

Löest, C. A., E. C. Titgemeyer, J. S. Drouillard, C. M. Coetzer, R. D. Hunter, D. J. Bindel, and B. D. Lambert. 2002. Supplemental betaine and peroxide-treated feather meal for finishing cattle. J. Anim. Sci. 80:2234-2240.

Lough, D. S., E. C. Prigge, W. H. Hoover, and G. H. Varga. 1983. Utilization of ruminally infused acetate or propionate and abomasally infused casein by lactating goats. J. Dairy Sci. 66:756-762.

Mitchell, A. D., A. Chappell, and K. L. Knox. 1979. Metabolism of betaine in the ruminant. J. Anim. Sci. 49:764-774.

NRC. 2001. Nutrient Requirements of Dairy Cattle. 7th rev. ed. National Academy of Sciences, Washington, DC.

Purdie, N. G., D. R. Trout, D. P. Poppi, and J. P. Cant. 2008. Milk synthetic response of the bovine mammary gland to an increase in the concentration of amino acids and acetate. J. Dairy Sci. 91:218-228.

Rook, J. A. F. 1979. The role of carbohydrate metabolism in the regulation of milk production. Proc. Nutr. Soc. 38:309-314.

Rook, J. A. F., and C. C. Balch. 1961. The effects of intraruminal infusions of acetic, propionic, and butyric acids on the yield and composition of the milk of the cow. Br. J. Nutr. 15:361-369.

Rook, J. A. F., C. C. Balch, and V. W. Johnson. 1965. Further observations on the effects of intraruminal infusions of volatile fatty acids and lactic acid on the yield and composition of the milk of the cow. Br. J. Nutr. 19:93-99.

Wang, C., Q. Liu, W. Z. Yang, J. Wu, W. W. Zhang, P. Zhang, K. H. Dong, and Y. X. Huang. 2010. Effects of betaine supplementation on rumen fermentation, lactation performance, feed digestibilities, and plasma characteristics in dairy cows. J. Agric. Sci 148:487-495.

Wildman, E. E., G. M. Jones, P. E. Wagner, R. L. Bowman, H. F. Trout Jr., and T. N. Lesch. 1982. A dairy cow body condition scoring system and its relationship to selected production characteristics. J. Dairy Sci. 65:495-501. 